\title{
FISHERY LEXICAL ITEMS IN TANJUNG BALAI MALAY LANGUAGE
}

\author{
Yuliza Yuna ${ }^{1}$, Prof. Amrin Saragih, M.A., PhD. ${ }^{2}$, Dr. Rahmad Husein, M.Ed ${ }^{3}$ \\ English Applied Linguistics Study Program Postgraduate School, \\ State University of Medan \\ JL. Williem Iskandar Pasar V Medan Estate-Medan-Indonesia \\ yunayuliza@gmail.com ${ }^{1}$
}

\begin{abstract}
This research focuses on the observation of fisheries object, that is fishery lexical items in Tanjungbalai Malay language. Acquisition of data conducted in the one subistrict of Tanjungbalai, North Sumatra. Research was conducted using qualitative research method, specifically by translating the vocabulary data of fishery lexical items in Tanjungbalai Malay language. This study also uses ethno linguistic approach that views the relationship between language and cultural elements within Malay community in Tanjungbalai. The subjects of the study one person namely informant were live in Tanjungbalai who work as a fisherman. The ages range 41-85 years old. The instrument of collecting data were observation, recording, interviewing adopted by Miles, Huberman and Saldana (2014). The researcher observed the subject closely and interviewed them. Analysis conducted by researcher towards the collected data is the type of meaning analysis based on the classification of the percentage of names of fish, product derived of fishery, tools of fishery, activities related to fishery, and the last is qualities related to the fishery. By virtue of research, researcher accumulated 408 words as research data. All of data comprise of 5 kind of fishery lexical items with classification, where noun of fishery were names of fish 217 items, product derived of fishery 27 items, tools of fishery with 94 items, activities related to fishery 48 items, and the last is qualities related to the fishery 22 items as the fishery lexical items classification and the percentage of names of fish (53\%), product derived of fishery (7\%), tools of fishery (23\%), activities related to fishery (12\%), and the last is qualities related to the fishery(5\%).
\end{abstract}

Keywords : Fishery Lexical Items, Ethno linguistic; Tanjungbalai Malay Language

\section{INTRODUCTION}

Tanjungbalai is the one of the East coast municipalities in North Sumatera Province. It has 6 districts and 31 sub districts where borders of the Asahan regency. They use Tanjungbalai Malay language as their daily communication language. Language is very important for human being to do interaction with others. In communication, language and society are two things that cannot be separated. Language cannot exist if there are no people who use it to interact or communicate. Because language is a system of arbitrary vocal symbols by means of which a social group cooperate (Bloch and Trager in Hidayat, $2006: 22$ )

For the language, Tanjungbalai Malay language similar with Batubara language. Tanjungbalai's people speak Tanjungbalai Malay language in their daily activity from one generation to the next generation. But nowadays in Tanjungbalai Malay language, the researcher found that there are many lexis in Tanjungbalai Malay language that never use of young generation because of modernization. It cause many lexical items of Tanjungbalai Malay language has potential to endangered expecially in fisheries area because Tanjungbalai is the number two of the largest fisheries center in North Sumatra after Belawan.

Beside that the influence of technology and modernization is most effected in fishery lexical items in Tanjungbalai. The technology development could lead to certain words disappear and formed new word, besides that the time is also contributes to the change of everything. Time change as all things, there is no reason why language should escape this universal law (Saussure :2011).

Attitude toward language is also having significant effect on language. Language attitudes are the feeling people have about their own language variety or language varieties of other. For example in 
English language, attitude to language appear to be important in language restoration, preservation, decay or death (Baker : 1995).

For example looking at Kamus Bahasa Melayu Asahan (Wahid,2008) so many names of fishery items in Malay languages are not recognize anymore by Malay's young generation nowadays.

1. ambe or jormal/jokhmal ( how to catch fish by making two ponds of woods are tracked in a row to the left and right so that fish are forced to pass through the mouth uncang tied to a pole located in the middle of two ponds)

2. apik lempang (vice-officer)

3. cuban (Wood that is used as a mesh size when knitting fishing nets)

4. dokar/ dokakh (Angler fish that get lots of fish)

5. mangiso (Catching fish by pulling two ends of the web rope to the shore and citing the fish trapped inside)

6. pangilar/ pangilakh (Fish trap device in a small river made of wire mesh)

From the data, nowadays many young people in Tanjungbalai didn't know the meaning of this fishery words because they never hear and use those words. For example, the old generation known vice-officer as apik lempang but now a day a young generation know vice-officer as mualim.

Based on the facts above the researcher interest to investigate more closely the condition of lexical occur in Tanjungbalai Malay language.

\section{LITERATURE REVIEW}

\section{Ecolingustic}

One of the issues that many people are talking about today is the environment. Climate change due to the greenhouse effect has implications for sea level rise, massively affecting social life in the slum area. It further suppresses the various environmental changes of the environment. In other words, pressure on the environment occurs. One of the most perceived changes is the shift in local community values, norms and culture. More specifically, there are changes in the language. Language is on the verge of being critical, increasingly difficult to "live," survive, and inherit in younger users and with the hegemony and dominance of several international, regional, and national languages that increasingly worried about the existence of minority languages in an area.

The mutual change between environment and language can be accessed through ecolinguistic studies. this ecolinguistic study is also known as the language ecology. There are four terms that refer to this study, namely linguistic ecology, ecological linguistics, the ecology of language / language ecology, and ecolinguistics (Lechevrel, 2009: 5). In other languages, it is also known as Ecologie des langues / Ecologie du langage, Linguistique ecologique, Ecologie linguistique and Ecolinguistique (France), Okologie der Sprache / sprachologie, Okologische Linguistics, Ecologie and Okolinguistic Linguistics (Germany), and Ecologia des las lenguas, Ecologia linguistic and Ecolinguistica (Spanish) (Lechevrel, 2009: 5 in al-Gayoni, 2010: 26).

This study was first introduced Einar Haugen in his article entitled Ecology of Language in 1972. Haugen prefer the term ecology language from other terms related to this study. The election is due to its extensive coverage, in which language experts can collaborate with other types of social sciences in understanding inter-language interactions (Haugan in Fill \& Mühlhäusler, 2001: 57)

\section{Definition of Ecolinguistics}

Language ecology may be defined as the study of interactions between any given language and its environment (Haugen, 1972, in Peter, 1996: 57). Fill (1993: 126) in Lindo \& Bundsgaard (eds.) (2000), defines ecolinguistics as follows Ecolinguistics is an umbrella term for '[...] all approaches in which the study of language (and languages) is in any way combined with ecology'.

Meanwhile, Mühlhäusler (1996), in one of his writings entitled ecolinguistics in the university, mentions Ecology is the study of functional interrelationships. The two parameters we wish to interrelate are language and the environment or ecology. Depending on whose perspective one takes one will get either ecology of language, or language of ecology. Combined they constitute the field of ecolinguistics. Ecology of language studies the support systems languages require for their continued wellbeing as well as the factors that have affected the habitat of many languages in recent times" (p.2) 
Crystal (2008: 161-162) in the dictionary of A Dictionary of Linguistics and Phonetics 6th Edition, explains that ecolinguistics (n.) In linguistics, an emphasis - reflecting the notion of ecology in biological studies - in which the interaction between language and the cultural environment is seen as central; also called the ecology of language, ecological linguistics, and sometimes green linguistics. An ecolinguistic approach highlights the value of linguistic diversity in the world, the importance of individual and community linguistic rights, and the role of language attitudes, language awareness, language variety, and language change in fostering a culture of communicative peace.

Meanwhile, the term ecology comes from the Greek Oikos, which means house, man's immediate surroundings. Ricklefs (1976: 1) in his book the economy of nature a textbook in basic ecology defines ecology as follows ecology is the study of plants and animals, as individuals and together in populations and biological communities, in relation to their environments - the physical, chemical, and biological characteristics of their surroundings.

In addition, Haeckel (1870) in Ricklefs (1976: 2) explains that By ecology, he wrote, we mean the body of knowledge concerning the economy of nature - the investigation of the total relations of the animal both to its organic and to its inorganic environment; including above all, its friendly and inimical relation with those animals and plants with ehich it come directly or indirectly in contact - in a word, ecology is the study of all the complex interrelations referred to by Darwin as the conditions of the struggle for existence.

Thus, ecolinguistic studies look more at the ecosystem link that is part of the human life system (ecology) with the language that humans use to communicate in their environment (linguistics). The environment is a language-based environment that presents various languages in a society. This dual / multilingual situation encourages language interaction. The physical environment with various social conditions greatly affects the speakers of the language psychologically in the use of the language (al-Gayoni, 2010: 31).

The term 'ecolinguistics' has been used to describe studies of language interaction and diversity; studies of texts such as signposts which are outdoors; analysis of texts which happen to be about the environment; studies of how words in a language relate to objects in the local environment; studies of the mix of languages surrounding pupils in multicultural schools; studies of dialects in particular geographical locations, and many other diverse areas. The multiplicity of approaches arises from different understandings of the concept of 'ecology', from a very broad concept of 'the interaction of some things with other things' to narrow concepts such as 'related to environmentalism'.

Steffensen and Fill (2014: 7) identify four different interpretations of ecology that lie behind the different approaches. The first approach sees language as existing in a symbolic ecology, where different languages interact with each other in a given location. The second approach sees language as part of a socio cultural ecology where it shapes societies and cultures. The third approach is concerned with cognitive ecology and how the cognitive capacity of organisms affects how they adapt to their environment. Finally, there is a natural ecology which is concerned with the relationship of language to its biological and physical environment.

\section{Scope of Ecolinguistic}

The discipline of ecolingusitics is traditionally divided into two main branches, eco-critical discourse analysis and linguistic ecology. Eco-critical discourse analysis includes, but is not limited to, the application of critical discourse analysis to texts about the environment and environmentalism, in order to reveal underlying ideologies. In its fullest formation, it includes analysis of any discourse which has potential consequences for the future of ecosystems, such as neoliberal economic discourse and discursive constructions of consumerism, gender, politics, agriculture and nature. Eco-critical discourse analysis does not just focus on exposing potentially damaging ideologies, but also searches for discursive representations which can contribute to a more ecologically sustainable society (Wikipedia).

Haugen (1970) in Mbete (2009: 11-12) mentions, there are ten space studies of the language ecology, among others,

1. Comparative historical linguistics, making the languages of kin in a geographical setting as the focus of the study to discover its genetic historical relation.

2. Demographic linguistics, studying a particular language community in an area to describe the quantity of resources (and quality) of the use of languages and their domains and their variety and registrations (sociolecs and functions).

3. Sociolinguistics, whose main focus is on the systematic variation between the language structure and the structure of the speaker's community. 
4. Dialinguistik, which focuses its study on the range of dialects and languages spoken by the language community, including in new habitats, or pockets of migration with its ecological dynamics.

5. Dialectology, reviewing and mapping the internal variations of the language system.

6. Philology, studying and tracking the potential of the writing culture and tradition, its propagation, the meaning of the connection with the study and / or fading of the culture, and the local writing tradition.

7. Prescriptive linguistics, studying language life in a given region, standardization of written language and spoken language, grammatical (as a local content that requires normative and pedagogical norm language).

8. Glotopolitik, reviewing and empowering also containers, or institutions handling language problems (specifically in the era of regional autonomy, special autonomy, as well as accompaniment of office and or hall of language).

9. Ethnolinguistic, anthropological linguistics or cultural linguistics that discusses the use of language, mode, style, mindset and imagery (Palmer, 1996 in Mbete, 2009), in terms of language usage patterns, ritual languages, local language-based advertising discourse creations.

10. Typology, dissect universality degrees and uniqueness of languages.

Based on the above ecolinguistic scope, this research is closely related to social ecology that deals with sociolinguistics and etno linguistics.

\section{FISHERY LEXICAL ITEMS}

In this case, the researcher will be collecting the categories of fishery lexical items in Tanjungbalai Malay language. Researchers focused this study on the vocabulary contained in the field of fishery in Malay Tanjungbalai. "A word is a unit of language that has one notions or rows of letters flanked by two spaces and has one meaning "(Chaer, 2007: 163). The word is the researcher in this case are words that are classified as the lexis of fishery. There are five categories of fishery lexical items in Tanjungbalai. They are fish's names, fishery's activities, fisheries tools, fishery's qualities and fishery product. For example in fish's names are kemudi kapal, panggang pulut, piso lipat, bare, unam, kupang, kuring balok, cincaru, kakao, alu-alu, lubin kertas, karotang, gorup, sindarsat. Fishery's activities are melabuh, melingkung pukat, melintang pasang, membubul, menangguk, menghalang ikan, misan, kameng. Fishery tools are teng,lukah, pengaum, ambe, tangkul pacak, bolat, tangkul bawah, pangkis, kalo, jormal ,bubu. Fishery's qualities are anyap, buruk, and manis and fishery's products are ikan asin, gule masam, anyang kopah.

\section{RESEARCH QUESTION}

What are the inventories of fishery lexical items used in Tanjungbalai Malay language?

\section{METHODOLOGY}

The method used in this research is descriptive research method. Jauhari (2007: 35) revealed that descriptive method is a research method that provides a description or description of a situation clearly without any treatment of the object under study. In accordance with the above explanation, the researcher tries to describe the problem of this research, namely the inventories of fishery lexical items used in Tanjungbalai Malay language. The form of research used in this study is qualitative. The form of qualitative research requires researchers to be careful in compiling the data of the research results systematically. According to Sugiyono (2012: 15), qualitative methods are used to obtain in-depth data, a data that contains meaning. Based on the opinion it is clear that qualitative research should be accompanied by sufficient data and must be arranged systematically.

The approach used in this research is the ethno linguistic approach. This approach sees language born in a local culture of society. This approach is taken because in accordance with the object of research to be conducted, namely fishery lexical items in Tanjungbalai Malay language. This ethno linguistic approach has guidance to the researchers' performance when collecting data in the field. 
According to Sibarani (2004: 51), "The method of collection used in anthrop linguistics is interview, observation, and document review."

The ethno linguistic approach used in this study also tends to follow the ethnographic flow of speech. Ethnography speaks of language research on cultural contexts. "Ethnography speaks assuming that speakers, by a certain intent, apply a linguistic source to social purposes in a situation prescribed by culture," (Palmer, 1996).

Data from this research is the vocabulary contained in fishery lexical items in Tanjungbalai Malay language. Sources of data of this research, namely the community who became the perpetrators as well as speakers of vocabulary that exist in fisheries and informants who know the field of fisheries in Tanjungbalai. Implementation research was conducted in a sub-district, namely Teluk Nibung. Researchers in this study successfully interviewed 1 informant who is considered to represent the city of Tanjungbalai overall. The informant is a proposal of the local community because it is classified as a figure who really understand about the fishery in Tanjungbalai.

Informants in this study were selected based on certain criteria. According to Samarin (1988: 55- 62), "The terms of informant selection, that is aged over 30, choosing informants of the same sex, know the local culture and native speakers of language and dialect researched." Techniques done by researchers in obtaining data in the field is an interview technique. Interview technique was conducted to a fisherman related to the existence of fishery in Tanjungbalai and the vocabulary contained in it. Interview activities were conducted with the help of writing instruments and recording instruments. Data collection tools used in this study are interview instruments, video recording devices, and voice recorder. Researchers as a key instrument, ie as planners, implementers, analyzers, and research reporter. The data analysis techniques performed researcher, that is to record vocabulary based on the recording and interviewing, classifying vocabulary based on the type of fishery, giving meaning to the vocabulary based on data in the field, and drawing conclusions. This research was conducted in Tanjungbalai city precisely in Teluk Nibung sub-district.

Researchers in this study managed to interview an informant which is considered to represent the city of Tanjungbalai as a whole. The informant is a local community proposal because classified as a community leader. Research conducted by researchers in the city of Tanjungbalai produce data vocabulary fisheries amounted to 408 words. The overall data is a data obtained by researchers based on information from informants and experience of researchers. The overall data is then analyzed by the researchers based on classification names of fish, product derived of fishery, the tools of fishery, activities realted to fishery, and the last is qualities related to the fishery.

\section{FINDINGS AND DISCUSSIONS}

\section{The Data}

Data refers to the rough materials which researcher collected from the sources that she was studying. As previous mentioned, the objectives of the study is fishery lexical items in Tanjungbalai Malay language. Based on the analysis that has been done, there are 408 (four hundred and eight ) fishery lexical items have found in Tanjungbalai Malay language which divided into five categories. The most of fishery lexical items found is names of fish, there are 217 (two hundred and seventeen) names of fish, second is the tools for catching fish with 94 (ninety four) items, activity related to fishery with 48 (forty eight) items, product derived of fishery with 27 (twenty seven) items and the last is qualities related to fishery with 22 (twenty two) items.

Inventories of Fishery Lexical Items

\begin{tabular}{|l|l|l|}
\hline No & Aspect of Categories & LEXICAL ITEMS \\
\hline 1 & Noun of fishery & bare \\
& & cumi \\
& & gurita \\
& & ikan jinaha \\
& & ikan alu-alu \\
& & ikan aruan tasik \\
& & ikan badut \\
& & ikan bagok \\
\hline
\end{tabular}




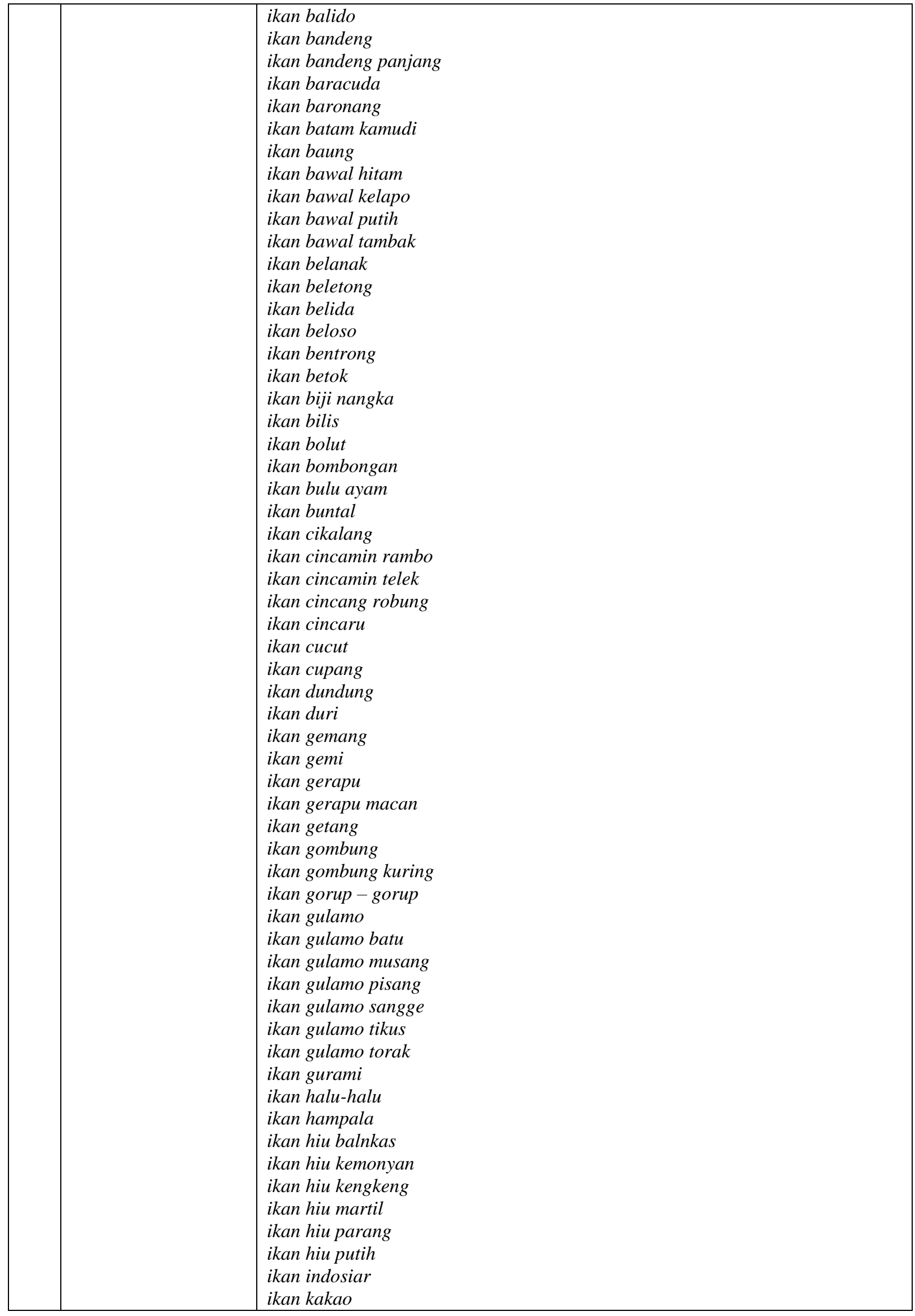




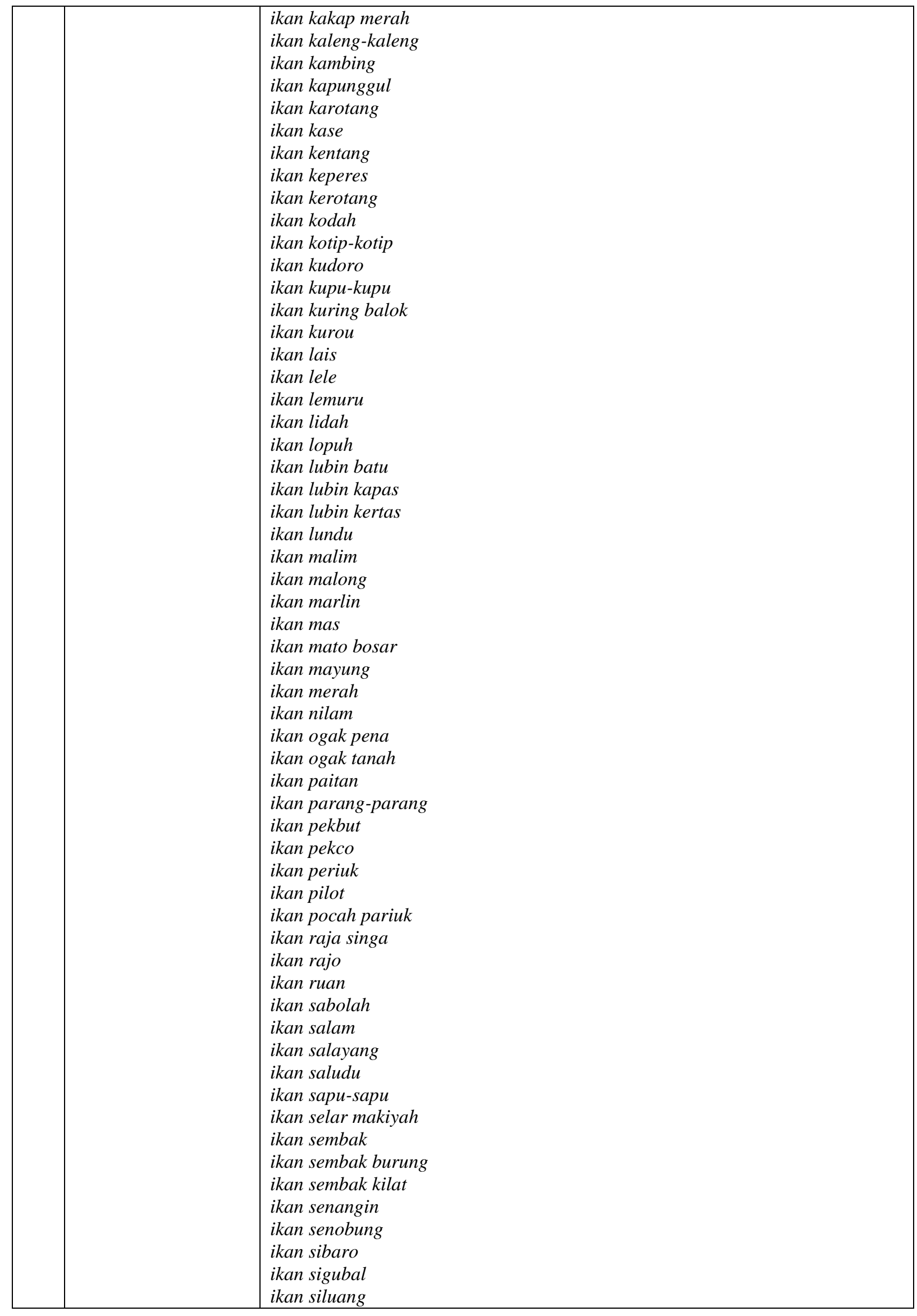




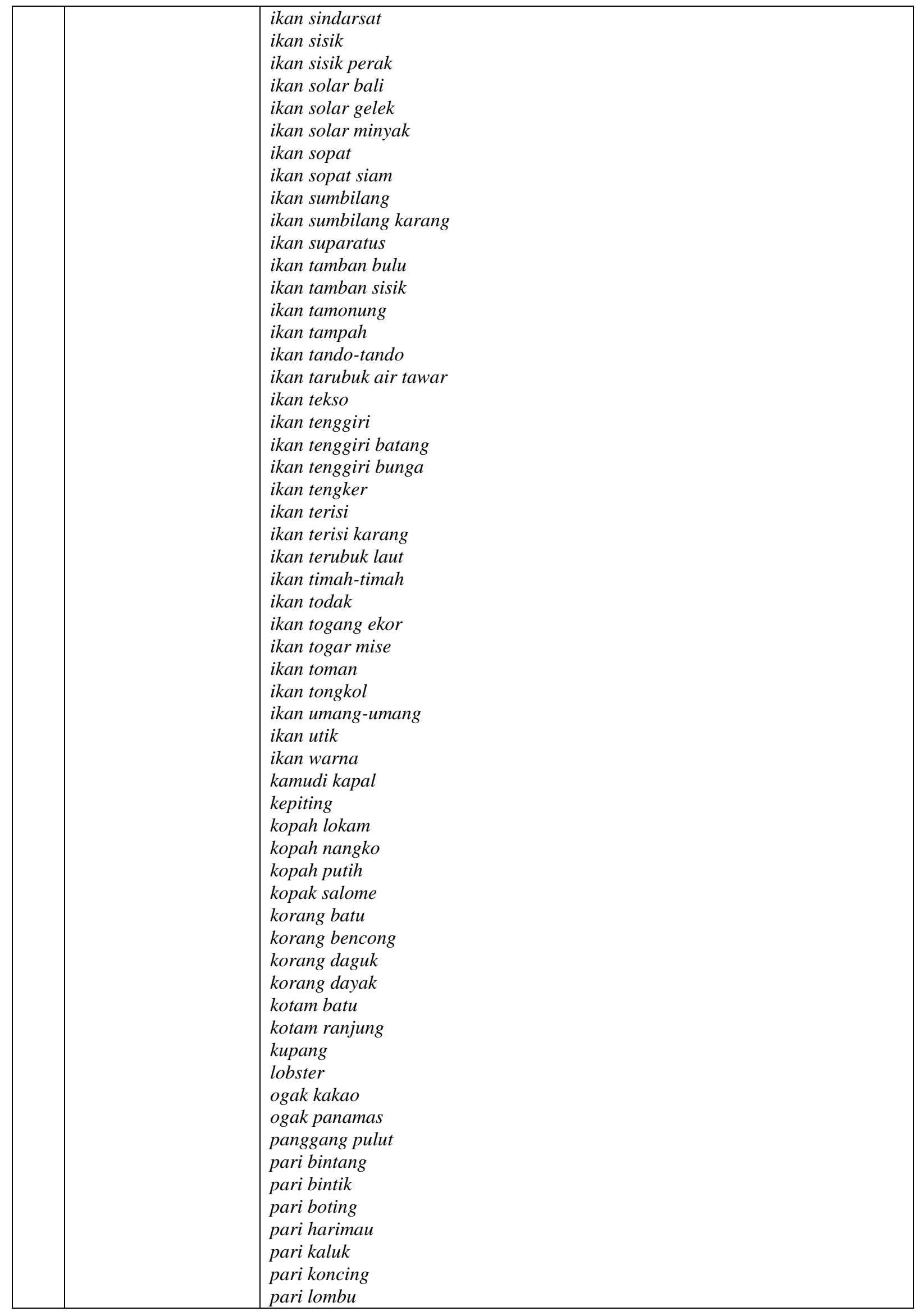




\begin{tabular}{|c|c|c|}
\hline & & 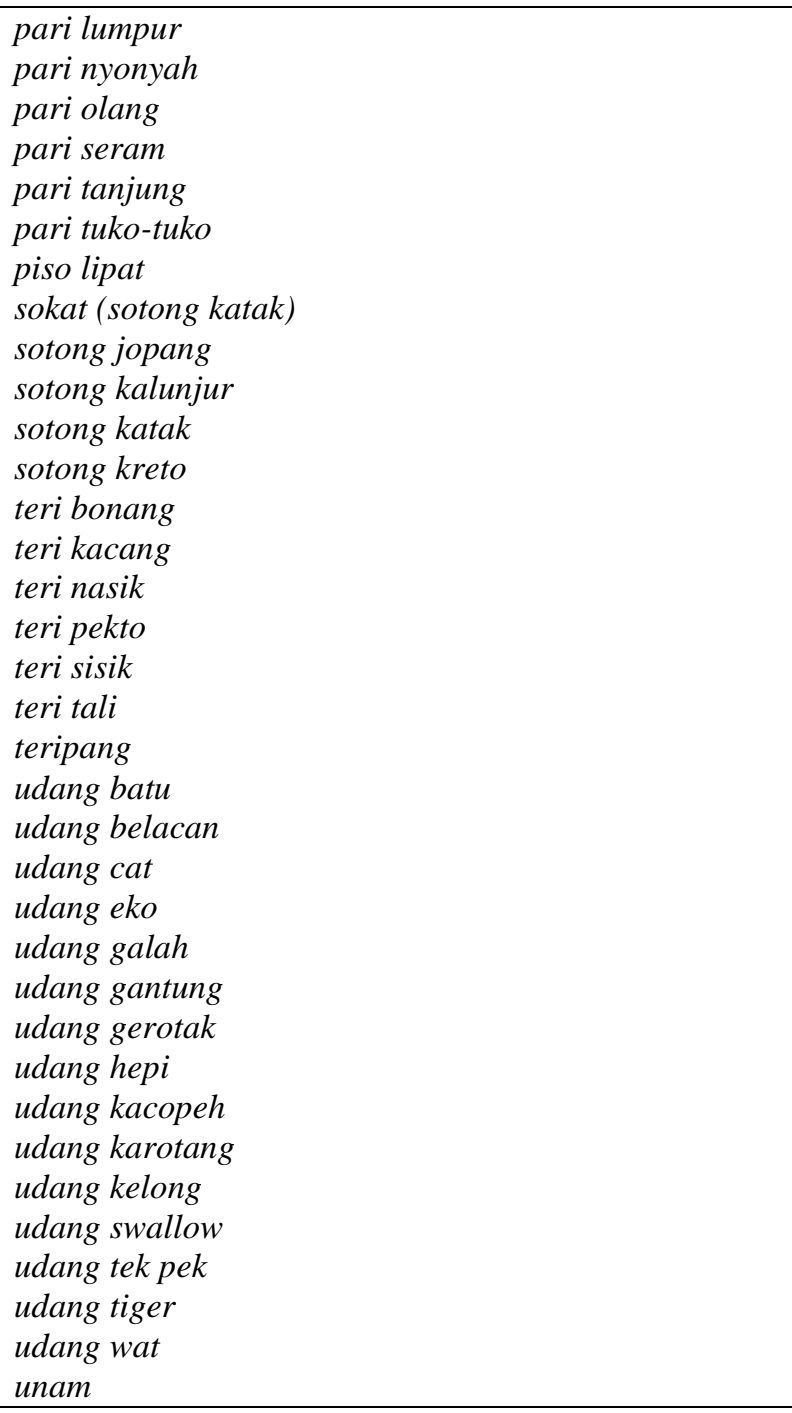 \\
\hline 2 & $\begin{array}{l}\text { Product derived for } \\
\text { fishery }\end{array}$ & 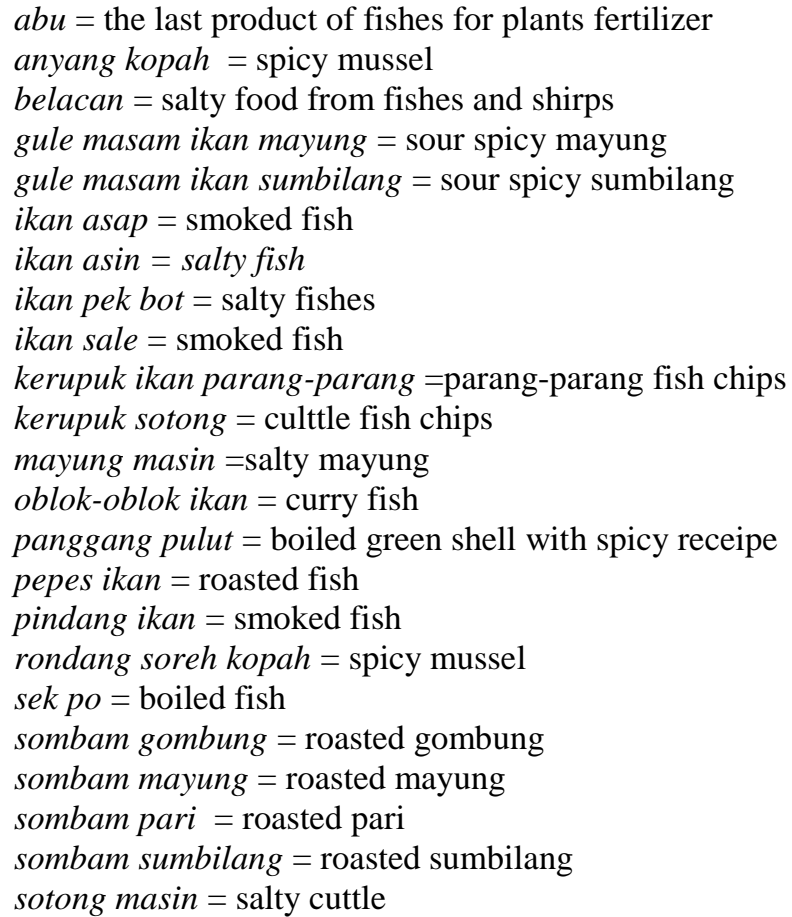 \\
\hline
\end{tabular}




\begin{tabular}{|c|c|c|}
\hline & & $\begin{array}{l}\text { teri masin = salty fishes } \\
\text { udang banting = whipped down shirps } \\
\text { udang pekhe = salty shirps } \\
\text { udang } \text { pukul =lapped shirps }\end{array}$ \\
\hline 3 & $\begin{array}{l}\text { tools for catching the } \\
\text { fishes. }\end{array}$ & 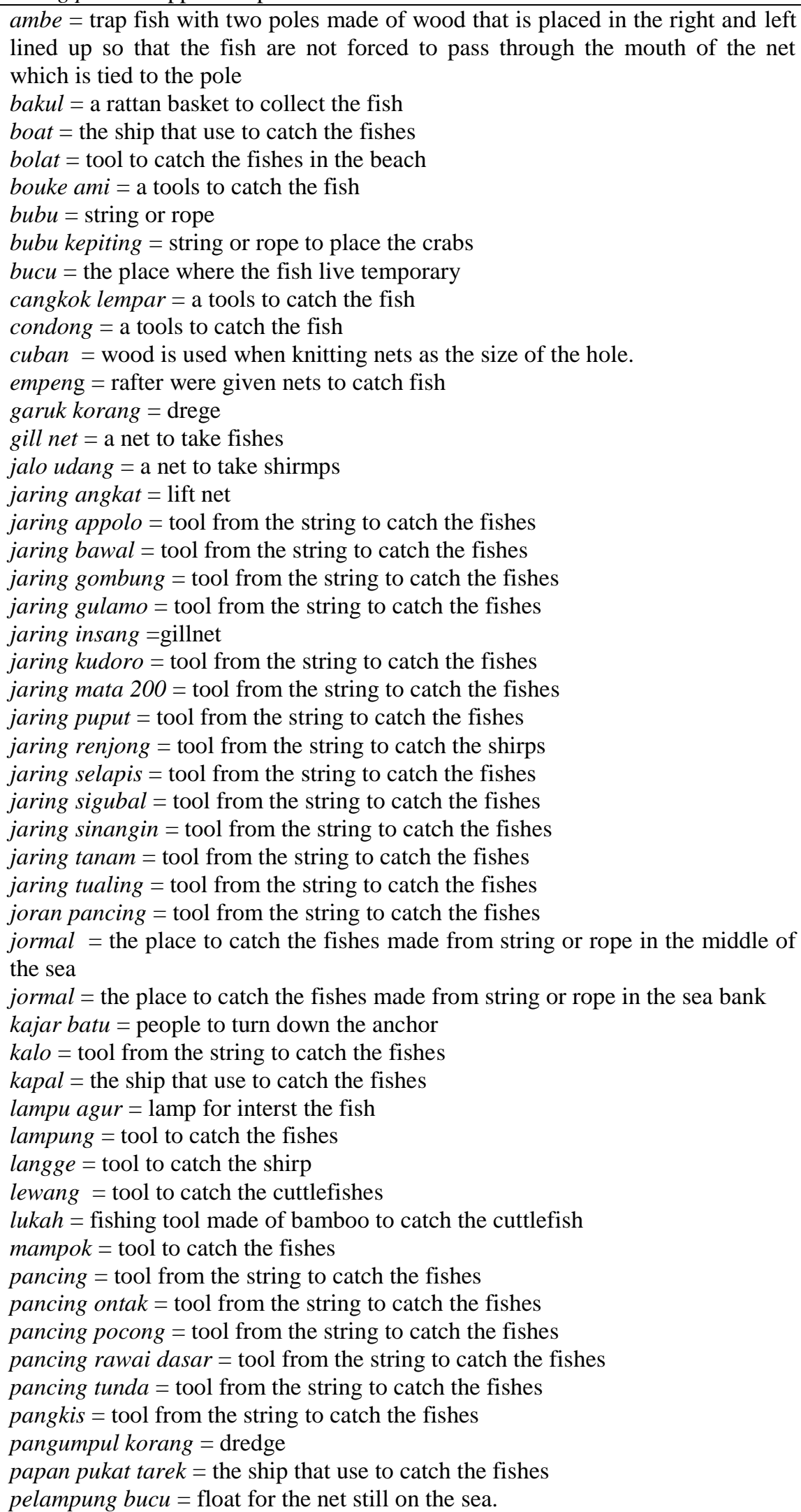 \\
\hline
\end{tabular}




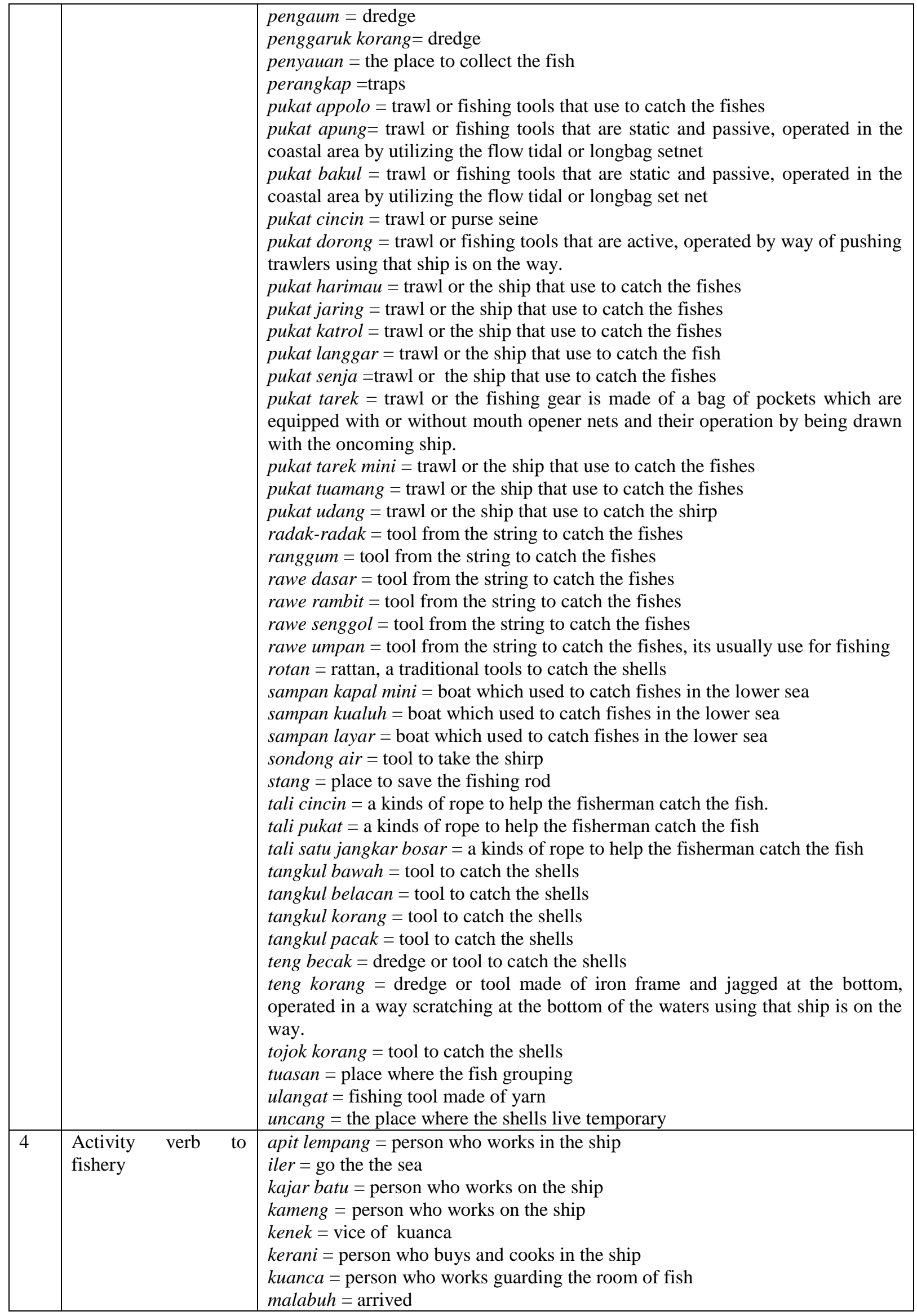




\begin{tabular}{|c|c|c|}
\hline & & 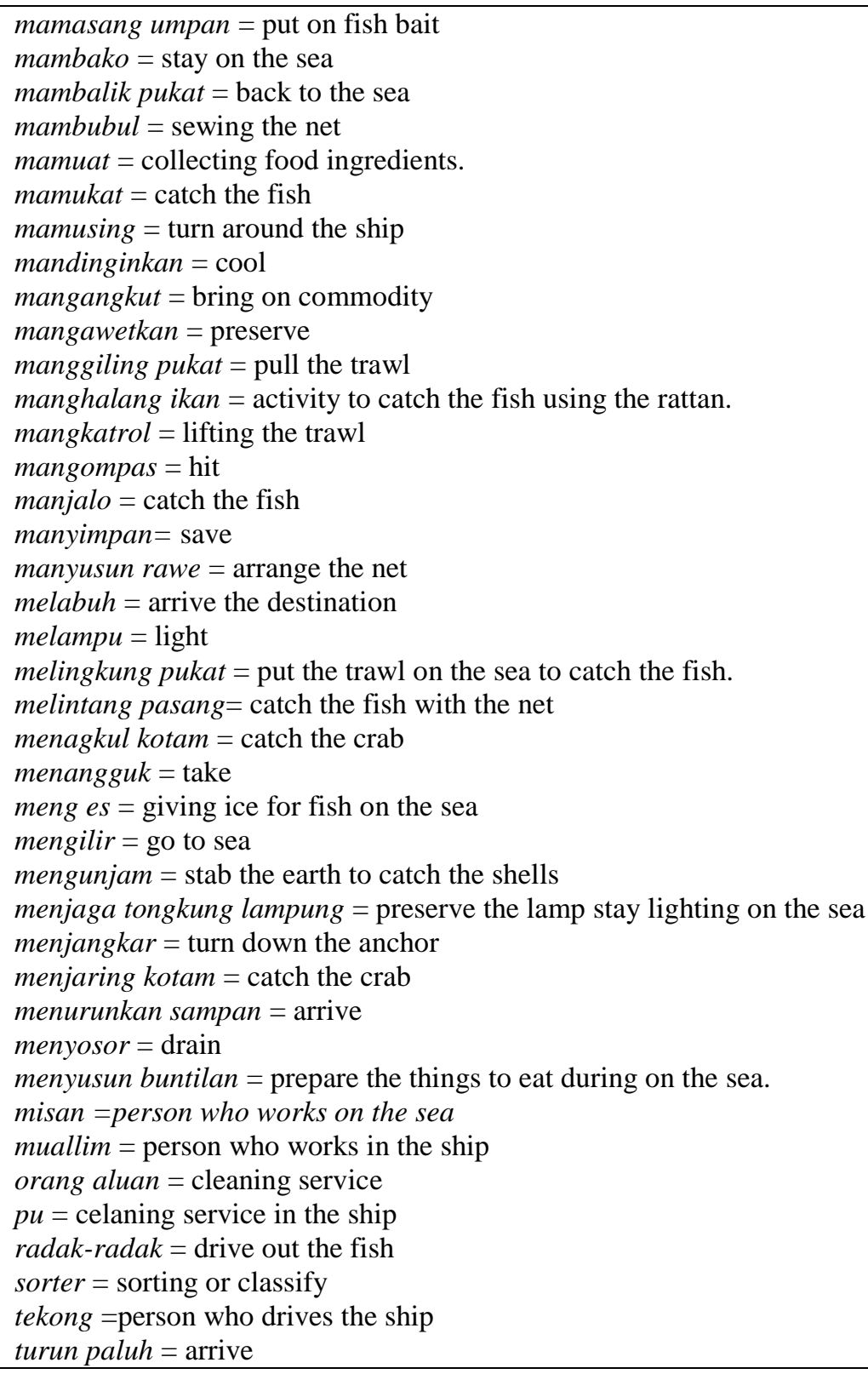 \\
\hline 5 & $\begin{array}{l}\text { qualities related to the } \\
\text { fishery }\end{array}$ & $\begin{array}{l}\text { alun }=\text { the high waves } \\
\text { anyap }=\text { no taste for food } \\
\text { arus suak }=\text { the bad water flow } \\
\text { basandar }=\text { the ship ropped } \\
\text { bebolit }=\text { tangled } \\
\text { buruk }=\text { the bad fish condition } \\
\text { gotas }=\text { deserted } \\
\text { jurnas }=\text { the ripples of water } \\
\text { keruh = bad water } \\
\text { mambonam }=\text { heavy } \\
\text { manis }=\text { the good condition about the fish taste } \\
\text { manukik = up } \\
\text { menggajah = tangled } \\
\text { menyauk } \text { karang = bad weather } \\
\text { pasang } \text { mati = bad season } \\
\text { payang }=\text { fail for make the tools of catch fishes. } \\
\text { sangkut = the boat is strand } \\
\text { tabolit }=\text { tangled }\end{array}$ \\
\hline
\end{tabular}




\begin{tabular}{|l|l|l|}
\hline & $\begin{array}{l}\text { tambatan = the ship dropped } \\
\text { teboting }=\text { the boat is strand } \\
\text { tesakat }=\text { the boat is strand } \\
\text { umbak }=\text { the low waves }\end{array}$ \\
\hline
\end{tabular}

\section{CONCLUSION AND SUGGESTION}

After analyzing the data there are 408 fishery lexical items in Tanjungbalai Malay Language with five categories, names of fish, tools for catching fish, activity related to fishery, product derived of fishery and the last is qualities and the most of fishery lexical items found is names of fish.

It is strongly suggested to the local Goverment of Tanjungbalai town to more pay attention about the maintenance and standardization Tanjungbalai Malay language through the establishment of standardized Tanjungbalai Malay language dictionary, formulized Tanjungbalai Malay grammar, and specified spelling system especially in fishery lexical items to make the language maintenance. Through this recorded material, the existance of Tanjungbalai Malay language especially fishery items can be handled down to the next generation. And the fishery and tourism ministry to more pay attention about the fishery such as culinary and handicraft from Tanjungbalai town.

\section{REFERENCE}

Al-Gayoni,YusradiUsman. 2010. Mengenal Ekolinguistik. Medan: http://yusradiusmanalgayoni.blogspot.co.id/2010/05/ mengenal ekolinguistik.html (20 Mei 2010)

Baker, C. 1995. Attitudes \& Language. United Kingdom: Multilingual Matters.

Hidayat, A.2006. Filsafat bahasa mengungkapkan hakikat bahasa, makna, dan tanda. Bandung : PT.Remaja Rosdakarya

Jauhari, Heri. 2007. Pedoman Penulisan Karya Ilmiah. Bandung: Pustaka Setia.

Miles,Matthew B., Huberman, A. Michael. Saldaña,Johnny.2014.Qualitative Data Analysis. United State of Ammerica : Sage

Palmer, Gary B. 1996. Toward a Theory of Cultural Linguistics. Texas: University of Texas Press.

Samarin, William J. 1988. Ilmu Bahasa Lapangan. Yogyakarta: Kanisius

Saussure, F. D. 2011. Course in General Linguistic. United States of America: Columbia University Press.

Sibarani, Robert. 2004. Antropolinguistik. Medan: Penerbit PODA.

Sugiyono. 2012. Metode Penelitian Kualitatif. Bandung: Alfabeta Bandung.

Wahid,R.A. 2008. Kamus Bahasa Melayu Asahan. Medan : LP2IK 